\begin{tabular}{cc} 
Revista de & Journal of Integrated \\
GESTÃO COSTEIRA Integrada COSTAL ZONE MANAGEMENT \\
\hline
\end{tabular}

\title{
Integrated coastal management in Brazil: analysis of the National Coastal Management Plan and selected tools based on international standards ${ }^{*}$
}

\author{
Leonardo Azevedo Klumb-Oliveira ${ }^{\circledR}$, a; Raquel Dezidério Souto ${ }^{\text {a }}$
}

\begin{abstract}
The Integrated Coastal Zone Management (ICZM) in Brazil is a political-institutional process, manifested in the establishment of the National Coastal Management Plan (NCMP) and in the formulation and implementation of specific tools for territorial planning in the coastal zone, as well as other activities related to ICZM in Brazil. This work analyses some official documents related to the Brazilian NCMP and to the frequently used tools for performing ICZM in Brazil: Macrodiagnostic of Coastal Zone, Orla Project and Coastal Ecological and Economic Zoning. The analysis is based on legislative, ecological and socioeconomic indicators, found in the Handbook for Measuring the Progress and Outcomes of Integrated Coastal and Ocean Management, published in 2006 by the Intergovernmental Oceanographic Commission. The results indicate adequacy of NCMP and tools on the definition and delimitation of the coastal zone, as the institutional processes of coordination and cooperation within the ICZM and about the diagnostics and the territorial planning of the coastal zone. However, the Brazilian NCMP as the cited tools still need to fully meet the major global goal of the ICZM, as internationally defined by the Joint Group of Experts on the Scientific Aspects of Marine Environmental Protection (GESAMP), with respect to the improvement of the life quality of coastal populations who depends on the sea resources and with respect to the environmental conservation of the Brazilian coastal zone. With the wide dissemination of results, is expected to contribute to the improvement of NCMPs and ICZM tools maintained worldwide, since we emphasize the importance of including the international general objectives of the ICZM, as well as inclusion the dimensions of sustainability in the ICZM processes, so try to ensure economic growth, coupled with respect to coastal populations and environmental conservation in coastal areas.
\end{abstract}

Keywords: Integrated coastal zone management, tools for coastal diagnostic and zoning, coastal indicators, sustainable development.

\section{RESUMO}

Gerenciamento costeiro integrado no Brasil: análise do Plano Nacional de Gerenciamento Costeiro e de instrumentos selecionados com base em parâmetros internacionais

O gerenciamento costeiro integrado no Brasil é um processo político-institucional, que se manifesta na instituição do Plano Nacional de Gerenciamento Costeiro (PNGC) e na formulação de ferramentas específicas ao planejamento territorial da zona costeira, além de outras atividades relacionadas ao gerenciamento. O presente trabalho apresenta a análise de documentos oficiais relacionados ao PNGC e a algumas das ferramentas frequentemente utilizadas na execução do GCI no Brasil: o Macrodiagnóstico da Zona Costeira, o Projeto Orla e o Zoneamento Ecológico e Econômico Costeiro. A análise tem por base os indicadores ecológicos, socioeconômicos e de legislação, encontrados no manual para medição do progresso e dos

\footnotetext{
(a) Corresponding author to whom correspondence should be addressed.

${ }^{\text {a }}$ Federal University of Rio de Janeiro, Center of Mathematics and Natural Sciences, Institute of Geosciences, Department of Geography, Postgraduate Program in Geography (PPGG/ UFRJ). Av. Athos da Silveira Ramos, 274, Cidade Universitária, Rio de Janeiro, RJ, Brazil. e-mails: <leoklumb@gmail.com>; <raquel.deziderio@gmail.com>
}

* Submission: 27 JUN 2014; Peer review: 21 JUL 2014; Revised: 29 NOV 2014; Accepted: 6 DEC 2014; Available on-line: 8 DEC 2014

This article contains supporting information online at http://www.aprh.pt/rgci/pdf/rgci-531_Klumb-Oliveira_Supporting-Information.pdf
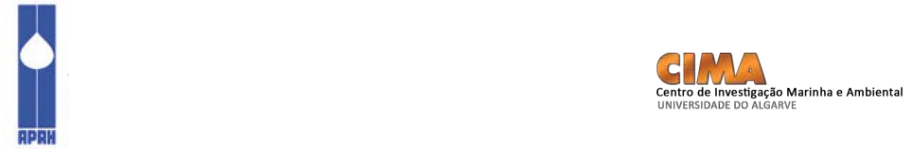
resultados do gerenciamento integrado costeiro e oceânico (Handbook for Measuring the Progress and Outcomes of Integrated Coastal and Ocean Management), publicado em 2006 pela Comissão Oceanográfica Intergovernamental. Os resultados indicam adequação do PNGC e das ferramentas selecionadas quanto à definição e delimitação da zona costeira, quanto aos processos institucionais de coordenação e cooperação no âmbito do GCI e quanto ao diagnóstico e ao planejamento territorial da zona costeira. No entanto, tanto o PNGC quanto as ferramentas analisadas ainda precisam melhor atender à meta global do GCI, como definido internacionalmente pelo Grupo Integrado de Especialistas sobre os Aspectos Científicos da Proteção Ambiental Marinha (acrônimo inglês: GESAMP), no que concerne à melhoria da qualidade de vida das populações costeiras que dependem dos recursos do mar e quanto à conservação ambiental da zona costeira brasileira. Com a ampla divulgação dos resultados, espera-se contribuir para a melhoria dos PNGCs e de ferramentas de gestão costeira mantidos em todo o mundo, uma vez que ressalta-se a importância da inclusão dos objetivos gerais do GCI a nível internacional, além da inclusão das dimensões da sustentabilidade nos processos de GCI, de modo a tentar garantir o crescimento econômico, aliado ao respeito às populações costeiras e à conservação ambiental nas zonas costeiras.

Palavras-chave: Gerenciamento integrado da zona costeira, ferramentas para diagnóstico e zoneamento costeiros, indicadores costeiros, desenvolvimento sustentável.

\section{Introduction}

The coastal zone gives the perception of a vast and seemingly endless ocean which changes as its waters collide with the continental edges, giving rise to a geographic area that represents the transition from a wet to a dry environment. The coastal zone, as initially defined by the Brazilian Federal Law $N^{0}$. 7661, dated $16^{\text {th }}$ May 1988 , is defined as "the geographic space of interaction of air, sea and land, including its resources, renewable or not, covering maritime and terrestrial zones, which will be defined by the Plan" (authors translation).

Komar (1988) highlights the diversity and temporality of the uses of the coastal zone, in addition to its sensitivity to climatic, hydrodynamic and social events, weakens the environment and emphasizes the need for implementing planning and management policies that aim to regulate land uses and mitigate the residual effects of the conflicts. Port activity with its collective logistics, tourism, fisheries, industrial development and real estate growth, exemplify the activities of more than $50 \%$ of the world's coastal population (Bird, 1996), and are some of the variables of the equation of the region. In a suitable illustration, the same author points out that if all the inhabitants of the world's Coastal Zones decided to go to the coast at the same time, there would be less than $13 \mathrm{~cm}^{2}$ of space for each one of them.

The spatial localization and conformation of coastal municipalities in Brazil actually are reflections of a historical pattern of coastal occupation: "the first Lusitanian settlements in Brazilian lands were located, with very few exceptions, in the coastal zone" (Moraes, 2007: 33). Considering that Brazil is a territory whose colonization manifested itself through the exploitation of resources to be exported to European markets, it is natural that urban occupation was originated in the coastal zone, since export activity logistics is favored by the proximity to the ocean. This pattern is critical, given that coastal areas are among the most dynamic areas of the world, in relation to both their physical and socioeconomic aspects.
Since that environmental concerns extend from air and water pollution to plans of land use and occupation (Ferreira, 1998), greater emphasis is being given to the integrated management that guides and constrains the use of natural resources, aiming to preserve for future generations. Following this view, diagnostic activities, zoning and planning are essential to the success of the integrated coastal zone management (ICZM) process in countries bordering the sea.

The ICZM is a dynamic process which aims, through a set of actions and inter-sectoral participation, to improve the quality of life of people living in the coastal zone and promote sustainable development by protecting ecosystems and coastal resources. According to Gesamp (1996), the approach used in the ICZM comprises four components: geographic, temporal, sectoral and political-institutional. Its development process involves generation of five consecutive stages:

i) identification and preliminary evaluation of relevant aspects;

ii) preparation of the program;

iii) formal adoption and funding;

iv) implementation; and

v) evaluation.

The process is continuous and restarts at the end of the fifth stage, until the program is perfected (GESAMP, 1996). Since it is an ongoing process, the perfection is a goal that will never be achieved.

The ICZM is consistent with the sustainable development objectives, since it seeks to integrate the economic, social, ecological, and political-institutional dimensions of the coastal zone, as seen in the overall goal of the ICZM: Integrated Coastal Management (ICM) is a process that unites government and the community, science and management, sectoral and public interests in preparing and implementing an integrated plan for the protection and development of coastal ecosystems and resources. The overall goal of ICZM is to improve the quality of life of human communities who depend on 
coastal resources while maintaining the biological diversity and productivity of coastal ecosystems. (GESAMP, 1996: 2)

Pickaver et al. (2004) point out that the ICZM is an important tool to incorporate the conservation and sustainable use of marine and coastal biodiversity. Given the plurality of contrasting niches in the coastal zone, the need arose for a specific policy for the coast, which would promote the development of economic and tourism activities, while protecting environmental, cultural, heritage and historical values (Freitas, 2007).

The National Coastal Management Plan (NCMP) was instituted in Brazil by Federal Law $\mathrm{N}^{\mathrm{o}} 7661$, dated $16^{\text {th }}$ May 1998, which, according to Diegues (2001), aims to promote rational use of the coastal zone resources, in order to raise the population quality of life, and to protect its natural, historic, ethnic and cultural heritage. This Law established only the main guidelines of coastal management and the actions of states and municipalities, standardizing the methodology to be applied (Freitas, 2007). Later, the NCMP was approved by the Resolution № 001 , dated $3^{\text {rd }}$ December 1990, of the Brazilian Interministerial Commission of the Resources of the Sea (ICRS) (Portuguese acronym: CIRM), which provides objectives, guidelines and programmed actions, tools, rules for the macro diagnostic and the monitoring of the Brazilian coastal zone. This Resolution establishes the competencies and the source of resources to make operational the Brazilian NCMP.

Posteriorly, the Resolution №. 005, dated $27^{\text {rd }}$ November 1997, revised the Brazilian NCMP, establishing general standards for environmental management of the Brazilian coastal zone, determining that the boundaries in which the guidelines of coastal management are to be followed, delineating two bands covered by the plan the maritime band, which corresponds to the Brazilian territorial sea; and terrestrial band, which corresponds to the group of coastal municipalities under direct or indirect influence of the sea, even if not situated right on the waterfront.

Federal Decree N ${ }^{\mathrm{o}} .5300$, dated $7^{\text {th }}$ December 2004, which regulated the Federal Law № ${ }^{0} 7661 / 88$, provides more specific rules for use and occupation of the coastal zone, establishing criteria for the management of the waterfront. This Decree adopts two bands and creates another one, both of them used as guidance on the application of Orla Project: the coastline, delimited on the sea side by the $10 \mathrm{~m}$ isobath and on land by the linear distance of $50 \mathrm{~m}$ in urbanized and of $200 \mathrm{~m}$ in nonurbanized areas, from the high tide line (or the end limit of adjacent terrestrial ecosystem).

The Brazilian NCMP is based on the decentralization of strategy implementation and decision-making, which specifically places the municipalities in the sphere of

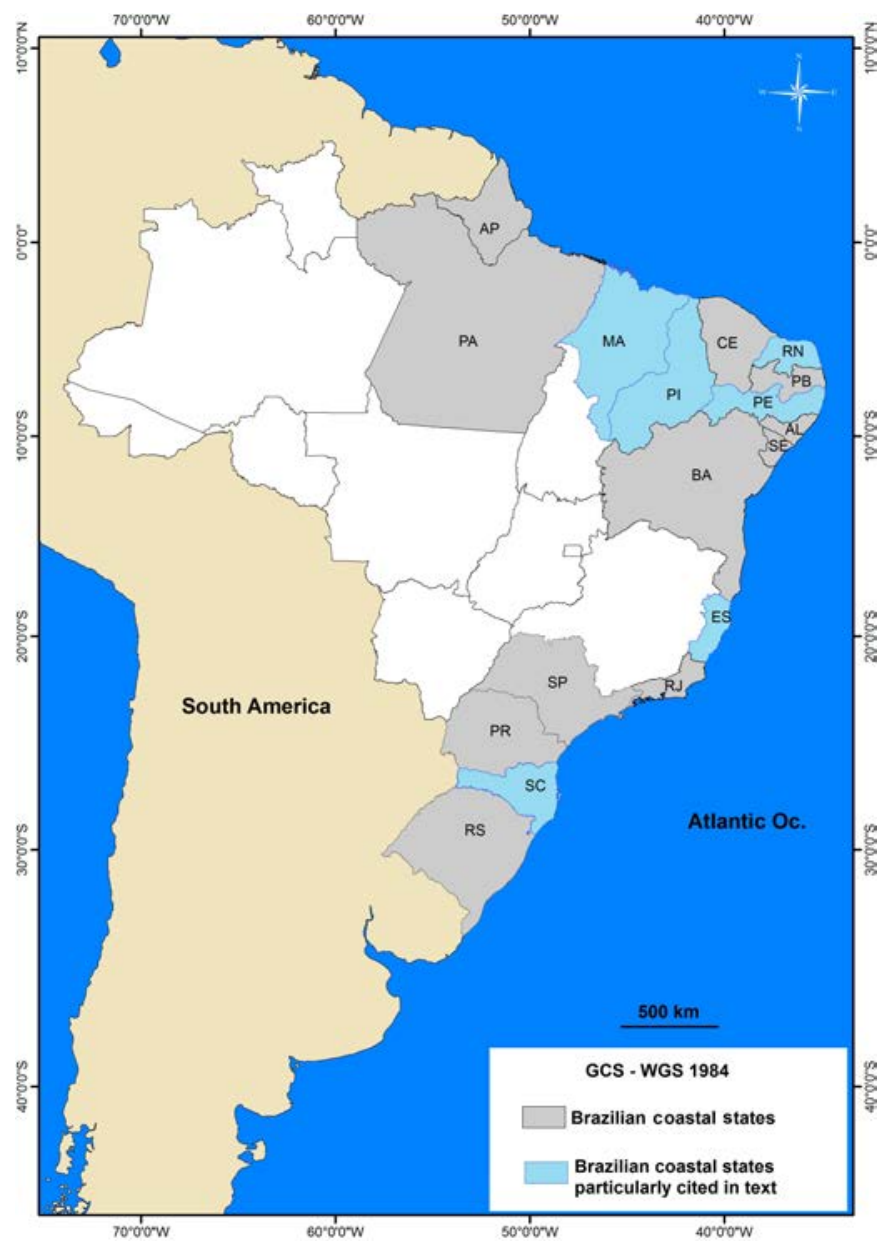

Figure 1 - Brazilian coastal states, highlighting the states particularly mentioned in the text.

Figura 1 - Estados costeiros do Brasil, com destaque para os estados particularmente mencionados no texto.

local implementation. This fact is very important, since municipalities acquire the knowledge of the coastal aspects and its environmental problems in more detail than the National Level.

The NCMP also expect that coastal municipalities implement their Municipal Coastal Plans (MCP), in accordance with the NCMP and State Coastal Plan (SCP) guidelines.

This Brazilian coastal management strategy, which includes the three levels of government action, favors the application of the principles of sustainable development. But, the sustainable development in the coastal zone also requires the adoption of holistic and systemic approaches. The holistic approach requires an interdisciplinary overview that integrates different processes due to the wide diversity of the coastal zone components.

The systemic approach evaluates the overall system and its component systems, keeping in mind the principle that the whole is not merely the sum of its parts, as described by Bossel (1999: 10): In complex real systems, 
this is a recursive relationship: systems depend on other systems that depend on yet another set of systems, and so on. (...) The human societal system, its component systems, and the resource and environmental system on which they depend, are complex dynamic systems.

The complexity involved in real dynamic systems requires extensive use of information derived from the formulation and application of indicators, to track the progress or the state of its aspects. Such indicators are essential to support management in any geographical scale. However, to be really useful, these indicators must be chosen carefully to provide information on the most relevant aspects of the problem. Another warning relates to the care needed in formulating the associated indices, so that the obtained information is more accurate and meaningful as possible. An excellent list of desirable characteristics for indicators in general can be obtained from Meadows (1998).

According to the planning for the ICZM, some tools that promote diagnosis and management of the coastal zone in Brazil are highlighted: Coastal Ecological Economic Zoning (CEEZ), Coastal Zone Macrodiagnostic (hereafter referred to as Macrodiagnostic) and Waterfront Integrated Management Project (hereafter, Orla Project).

In Brazil, Ecological Economic Zoning (EEZ) is an instrument for planning and managing the territory according to Federal Law $N^{\circ}$. 6938, dated $31^{\text {th }}$ August 1981 (that provides the national environmental policy in Brazil). The EEZ was posteriorly regulated by the Federal Decree $N^{\mathrm{o}}$. 4297, dated $10^{\text {th }}$ July 2002, that regulates the article 9, section II, of the Federal Law $\mathrm{N}^{\mathrm{o}}$ 6938/81: Art. $9^{\text {th }}$ - are instruments of national environmental policy: (...) II - the environmental zoning; (...)" (authors translation).

The competences for the execution of the EEZ in Brazil are established by the Presidential Decree, dated $28^{\text {th }}$ December 2001: Provides for the Coordinator Commission for the Ecological and Economical Zoning of the National Territory and the Permanent Working Group for the implementation of ecological-economic zoning, institutes a permanent Working Group for the Implementation of ecological-economic zoning, called Consortium ZEE-Brasil, and gives other measures.

Brazil does not has a federal legislation dedicated to regulate the CEEZ in the country. This subject is treated as one of the instruments provided by the ICRS Resolution $\mathrm{N}^{\mathrm{o}} 005 / 97$, which establishes the observance of the zoning criteria for the national territory: The coastal ecological-economic zoning is the guiding instrument for the regional planning process, required to obtain the environmental sustainability conditions to the development of the coastal zone, in accordance with the guidelines of the ecological-economic zoning of the national territory. (authors translation)

According to Federal Decree №. 4297/02 (Chapter 2), Brazilian States can develop its EEZ in conjunction and cooperation with the Federal Government: Art. $6^{\text {th }}$ - Incumbent upon the Federal Government develop and implement national or regional EEZ, especially when you have as object biome considered national patrimony or that should not be treated a piecemeal manner. (...) $\S 1^{\text {st }}$ The Federal Government may, by entering appropriate document, develop and implement the EEZ in conjunction and cooperation with the States, the conditions required this Decree. (...)Among the technical assumptions, the enforcers of EEZ must submit: I - comprehensive reference term; II - coordination team composed of technical staff enabled; III - methodological compatibility with the principles and criteria approved by the Coordinating Committee of the Zoning Ecological-Economic National Territory, established by Decree of December 28 $8^{\text {th }}, 2001$ (...). (authors translation)

According to the $3^{\text {rd }}$ article of the Presidential Decree dated $28^{\text {th }}$ December 2001, the works of zoning will be conducted using an interdisciplinary approach and systemic view, enabling the analysis of cause and effect, allowing the establishment of relationships of interdependence between physical and biotic subsystems and socio-economic.

In some initiatives developed in Brazilian States, like the CEEZ of Espírito Santo (ES), the diagnosis of nature sensitivity and social potential allows to define areas relatively vulnerable to use and takes into consideration physical and social variables at local and regional levels, in order to suggest a use for each area after assessing its resilience. Thus CEEZ emerges as an important planning tool, by using indicators of socioenvironmental variables, which, when combined, can generate social vulnerability indexes. These indexes should be taken into account during decision making for installing enterprises, identifying priority conservation areas, localizing urban settlements, together with the aspects of valuation and valorization of the waterfront (Moraes, 2007).

The Orla Project confers a local character to the implementation of coastal territorial planning, since 2004. It is based on the premise of joint management of the waterfront's land-use and occupation by the federal, state, and municipal governments, and society.

The proposal of the Orla Project was included as priority in the Brazilian Federal Action Plan for the Coastal Zone (FAPCZ), from 1998, under the Ministry of Environment, Water Resources and Legal Amazonia (Portuguese acronym: MMA) (GI-Gerco, 1998: 19): It is observed, so that both the seafront, as the track Navy Coastal Zone, are under federal domain, and its man- 
agement, largely defined in the structure which deals with all the features and all dimensions, with such national wealth in the custody of the Union. This fact justifies that the programming of a series of activities, consolidated a specific line of work of the Federal Action Plan, is dedicated to coordination process led by Union Heritage Secretariat in implementation of the "Maritime Orla Project", dedicated to review the federal performance in matter, updating the concepts and measurements used and reviewing the emphyteusis and grants use of these spaces, taking into account, including, the guidelines included in the environmental legislation of the country. Emerge here, clearly, a priority of the Federal Action Plan. (authors translation)

Since 2001, some Brazilian states were instituted as pilots of the Orla Project: Rio Grande do Norte (RN), Piauí (PI), Santa Catarina (SC) and Espírito Santo (ES) (Oliveira \& Nicolodi, 2012). In 2003, the Secretary of the Heritage of the Union (Portuguese acronym: SPU), an agency under the Ministry of Planning, Budget and Management (Portuguese acronym: MP), in partnership with the Ministry of Environment, was incorporated into the management of the Orla Project.

The objective of the Orla Project is to "implement an Integrated Management Plan to direct the use and occupation of land in bands along the rivers and seas" (MMA, 2005). The main assumptions of the Orla Project are the following:

i) the coastal zone is seen as a national asset, with its use subject to environmental protection (according to $\S 4$ of Article 225 of the Brazilian Federal Constitution, dated on 1988);

ii) public lands would be seen through their socioenvironmental function; and

iii) civil society transcends from the position of the beneficiary to that of co-manager in the development and monitoring of policies, together with other federal entities.

Hence, the Orla Project is a joint initiative between the policies of land and socio-environmental heritage, and its guidelines value the actions that promote sustainable use of coastal resources and the strengthening of links between the different stakeholders (MMA, 2005). Thus, the Orla Project aims to regulate the use of coastal space, combining physical environment support variables with current socioeconomic and urbanization scenarios, as well as to try to preserve the parts not yet urbanized or in the process of urbanization.

Macrodiagnostic is an instrument of the Federal Decree $\mathrm{N}^{\mathrm{o}} 5300 / 04$, and aims to gather information, on a national scale, on biophysical and socioeconomic characteristics of the coastal zone, in order to dictate actions of preservation, conservation, regulation and supervision of natural and cultural heritage. The initiative originated in the ICZM assessment process conducted in Brazil in the early 1990s, which culminated in its first national coastal Macrodiagnostic (MMA, 1996).

The Macrodiagnostic published in 2008 uses environmental risk analysis as a methodological basis and considers three dimensions: natural risk, technological risk and social risk; in addition to three basic criteria: sensitivity of natural systems, density and potential expansion of the productive structure, and degree of criticality of the habitability conditions (MMA, 2008). Taussik (2007) quotes a useful example of managing coastal risk in United Kingdom and alleges that the legislation for the regulation of the development and for the protection of coastal populations against coastal flooding, erosion and instability share the objective of the minimizing the risk.

This work aims to contribute with the ICZM process in Brazil, presenting the key strengths and weakness of the Brazilian NCMP and of some tools used to execute the coastal management in Brazil: Macrodiagnostic of Coastal Zone, Orla Project and Coastal Ecological and Economic Zoning. More widely, this work aims to expose some aspects of the legal documents related to the ICZM in Brazil, in comparison with international standards, and propose the analysis of Brazilian official documents related to the ICZM in the country (which regulates the NCMP and the selected tools) with some recognized international concerns standards, from the IOC and from the GESAMP. Thus, this work aims to collaborate with others ICZM processes, developed worldwide.

The results indicate that the official documents related to Brazilian NCMP and the cited tools provide detailed definition and delimitation of the coastal zone of Brazil; of the same mode, these analyzed official documents provide the rules for the institutional processes of coordination and cooperation within the ICZM and for the diagnostic and the territorial planning of the coastal zone. However, the NCMP as the cited tools still need to fully meet the major global goal of the ICZM, as internationally defined by Gesamp (1996), with respect to the improvement of the life quality of the coastal populations who depends on the sea resources and with respect to the environmental conservation.

\section{Material and methods}

To achieve the goals, this work presents the analysis of the Brazilian NCMP and of the cited coastal management tools, based on legislative, ecological and socioeconomic indicators, found in the Handbook for Measuring the Progress and Outcomes of Integrated Coastal and Ocean Management, published in 2006 by the Intergovernmental Oceanographic Commission (IOC, 2006) and based on the overall goal of the ICZM, here- 
after referred to only as Handbook, according to the Joint Group of Experts on the Scientific Aspects of Marine Environmental Protection (GESAMP, 1996). In order to perform the analysis of the Brazilian NCMP and selected tools, we proceeded in two steps. Both are based in the Handbook, and in the overall goal of the ICZM, according to Gesamp (1996).

The first step consisted of an analysis of the legislation that detailed the Brazilian NCMP (ICRS Resolution $\mathrm{N}^{\mathrm{o}}$ 001/90 and ICRS Resolution № 005/97), according to criteria referred to the indicator "G2- Existence and adequacy of legislation enabling ICOM", from the Handbook. This indicator aims to support "integrated management through adequate legislation and regulations" (IOC, 2006: 24). In this way, the indicator adopt the parameters:

i) existence of legislation on coastal and marine resources and

ii) adequacy of the ICZM legislation.

Generic and more detailed provisions are presented too (IOC, 2006: 117). The adopted criteria for the analysis of the Brazilian NCMP were:

i) incorporating the sustainable development principles, specifically for oceans and coasts;

ii) supporting ICZM goals and objectives;

iii) establishing procedures for institutional coordination and cooperation and

iv) defining interventions and management activities under the ICZM scope.

This analysis was realized comparing some of the legal documents related to the Brazilian NCMP (ICRS Resolution $\mathrm{N}^{\mathrm{o}} 001 / 90$ and ICRS Resolution $\mathrm{N}^{\mathrm{o}}$ 005/97) with the adopted criteria. These Resolutions were selected because they detail the operationalization rules for the implementation of the ICZM in Brazil, presented in the NCMP dated on 1990 and its revision, on 1997.

The second step consisted of the analysis of the CEEZ (and some EEZ's initiatives referred to the coastal Brazilian States), the Orla Project and the Macrodiagnostic. The analysis adopts as reference the parameters of the socioeconomic indicators, SE1 to SE13 (IOC, 2006: 50) and to the ecological indicators, E1 to E9 (see supporting information) (IOC, 2006: 38), presented in the Handbook. The analysis focus on the:

i) coverage of cited socioeconomic and ecological parameters (supporting information) and

ii) ability to provide ecological and socioeconomic information pertinent for the Brazilian coastal management, having as reference the ICZM objectives as defined by GESAMP (1996).

In the same way, official documents referred to these three tools were discussed, according to the adopted criteria.

\section{Results and discussion}

\subsection{Analysis of Brazilian NCMP}

3.1.1. Analysis of the Brazilian NCMP regarding the sustainable development principles and the international goals and objectives of the ICZM

ICRS Resolution № 001, dated $3^{\text {rd }}$ December 1990, which approves the Brazilian National Coastal Management Plan (NCMP), adopts the systemic and holistic view, but addresses six principles, closely limited to environment (a little bit ecological) and political dimension of the sustainability:

1 - The National Coastal Management Plan will be developed and implemented based on the National Policy for Marine Resources.

2 - Protection of coastal ecosystems, which will be used in compliance with the criteria laid down by law, under conditions ensuring environmental preservation.

3 - Maintenance and expansion of the fishing capacity of the waters of the territorial sea, through the conservation of mangroves, estuaries and other coastal formations.

4 - Protection and rehabilitation of the remaining areas that are representative of natural ecosystems of the coastal zone.

5 - Control and rehabilitation of degraded and disfigured areas in the coastal zone.

6 -Rational use of resources of the coastal zone, through the knowledge of environmental dynamics, under a systemic / holistic approach.

The ICRS Resolution № 005 , dated $27^{\text {th }}$ November 1997, which approves the National Coastal Management Plan II (NCMP II), establishes general standards for environmental management of the coastal zone and creates the Integration Group of Coastal Management (Portuguese acronym: GI-Gerco). This resolution emphasizes, in the introductory section, the close relationship between the sustainability of human activities and environmental conservation, and expresses the commitment of the Brazilian government to the sustainable development of its coastal zone: The National Coastal Management Plan (NCMP) expresses the commitment of the Brazilian government to the sustainable development of its Coastal Zone, considered as a national heritage (...)

This commitment in ICRS Resolution № $005 / 97$ is represented by twelve principles, which includes the socioeconomic and cultural dimensions, beyond the environmental and political dimensions of the sustainability, presented in the ICRS Resolution № 001/90: The integrated management of Coastal Zone terrestrial and marine environment(...) The sustainable use of coastal 
resources (...) The consideration, on the terrestrial part, of the areas marked by socio-economic and cultural activity (...) and its area of immediate impact, from the effects of these activities, on shaping the coastal territory.

The sustainable development goals are markedly expanded in the ICRS Resolution № $005 / 97$, but the effects of socioeconomic activities are considered only on shaping the terrestrial and not the marine domain. This is a serious shortcoming, since offshore oil exploration is becoming increasingly important in Brazil. Another shortcoming of the approach adopted in the ICRS Resolution № $001 / 90$ and in the ICRS Resolution $\mathrm{N}^{\mathrm{o}} 005 / 97$ is that it does not define clearly the preservation of biological diversity and ecosystem productivity of the coastal zone, because it focuses on the sustainable use of natural resources (in the ICRS Resolution $\mathrm{N}^{\text {o }}$ 001/90), or physical changes in the coastal territory (in the ICRS Resolution № ${ }^{0}$ 005/97). The sustainable use of natural resources is strictly related to not extrapolate the load capacity of the ecosystems.

Both two ICRS Resolutions, do not provide tools or actions to improve the quality life of the coastal populations who depends on coastal resources, which is one of the global goals of the ICZM, according to Gesamp (1996).

On the other hand, both the ICRS Resolutions adopt components of the ICZM approach: geographic, temporal, sectoral and political-institutional, according to Gesamp (1996).

\subsubsection{Analysis of the Brazilian NCMP regarding insti- tutional coordination and cooperation}

The ICRS Resolution № ${ }^{0}$ 001/90 and the ICRS Resolution $\mathrm{N}^{\mathrm{0}}$ 005/97 establish the competencies for coastal management in Brazil for government sectors at the federal, state and municipal levels. The ICRS Resolution $\mathrm{N}^{\mathrm{o}} 005 / 97$ is more specific and provides mechanisms for cooperation, whether in the form of boards; or in the form of inter-sectoral and inter-agency coordination activities with relevant agencies and boards implemented by Ministry of Environment; or in joint activities with states and municipalities for the implementation of conservation units, promoted by the Brazilian Institute of Environment and Renewable Natural Resources (Portuguese acronym: IBAMA). The ICRS Resolution № ${ }^{0}$ 005/97 retains the authority of the Ministry of Environment as the main coordinator of the ICZM in Brazil, expands its powers and defines two groups to support its activities (GI-Gerco and a subgroup of Integration of States, linked to GI-Gerco).

GI-Gerco is a group of coastal management integration, formed under the ICRS, whose mission is to promote the coordination of FAPCZs. The Subgroup of Integration of States, has the mission of to promote the coordi nation of states among themselves and with the federal government on general coastal management issues in Brazil (Resolution № 001, 1997).

The duties of IBAMA, state and local governments remain the same under the ICRS Resolution № 005/97, with municipalities having the additional duty to uphold the compatibility of their tools of spatial planning with CEEZ (Resolution № 001, 1997).

The boards, provided by the ICRS Resolution $\mathrm{N}^{\mathrm{o}}$ 005/97 are groups suitable for coastal management, composed of representatives from public and private sectors and society organizations, allowing discussions and forwarding policies, plans, programs and actions involving the main actors of the coastal zone, being consistent with the participation principles explained in ICZM.

Thus, it is observed that the ICRS Resolution № $005 / 97$ is clear regarding the powers and duties of the main public actors in coastal management in Brazil and the definition of joint mechanisms between the three levels of government.

A noteworthy detail is that the sources of public funding for the implementation of NCMP in Brazil are defined in the ICRS Resolution $\mathrm{N}^{\mathrm{o}} 001 / 90$ and in the ICRS Resolution $\mathrm{N}^{\mathrm{o}}$ 005/97. Both the Resolutions do not clearly regulates the mandatory character of including the coastal management plans execution in the budgets of the three government levels, even if it has been established by the mentioned Resolutions.

\subsubsection{Analysis of the Brazilian NCMP regarding inter- vention activities}

ICRS Resolution № $001 / 90$ provides the execution of the CEEZ in Brazil and provides the use of the results like criteria for zoning, which will guide the intervention activities in the coastal zone.

In ICRS Resolution № 005/97, intervention activities are implied in the statement of one of the planned actions for coastal management, which requires compatibility of NCMP actions with public policies that focus on the coastal zone.

The government plays a lesser role on intervention activities in both Resolutions, since only interventions at the local level are clearly defined. Thus, the Brazilian government is limited to providing information or planning. More than that, the Brazilian government should act as a regulator of coastal areas, so as not to allow the prevalence of speculative and vested interests in coastal management related decision-making. The Brazilian NCMP could have a key role within the ICZM process in Brazil, providing the main guides for intervention actions. Hence, the main characteristic of the plans should be, precisely, the prediction of intervention actions in coastal areas. 
But specific rules for the intervention actions in the Brazilian coastal zone are provided by the Federal Decree $\mathrm{N}^{\mathrm{o}} 5300$, dated $7^{\text {th }}$ December 2004, which regulates the Federal Law $N^{0} 7661 / 88$. This providence was useful to establish some degree of governmental intervention for the coastal zone occupation and for the uses of its space and resources.

\subsubsection{Analysis of the Brazilian NCMP regarding defini- tion of management activities}

The ICRS Resolution № 001/90 and the ICRS Resolution $\mathrm{N}^{\mathrm{0}} 005 / 97$ predict numerous tools (management, diagnosis, or information), but differ as to the delimitation of coastal areas and the actions to be implemented for their management.

Regarding implementation of coastal management activities, ICRS Resolution № $001 / 90$ provides some tools for Brazilian ICZM: the EEZ, the coastal monitoring (with different levels of action), the information system for the ICZM in Brazil (Portuguese acronym: SIGERCO) and management plans (or programs), according to specific issues:
i) Implantation of Conservation Units Plan;
ii) Environmental Education Plan;
iii) Scientific Development and Diffusion of Adequate Technologies Plan;

iv) Programs to Support Emergences and Accidents;

v) Programs for the Ecotourism;

vi) Recovery of Degraded Areas Plans;

vii) Plan of Investments on collect, treatment and disposal of solid and liquid effluents and

viii) Plans for the management of watersheds.

Regarding implementation of coastal management activities, ICRS Resolution $\mathrm{N}^{\mathrm{o}} 005 / 97$ presents a set of actions whose objective is to systematically regulate ICZM in all levels of government in Brazil. These actions address coordination, implementation, integration and planning, aiming at producing plans and instruments designed to support coastal management. Furthermore, provides seven tools for the ICZM in Brazil:

i) the State Coastal Plan (SCP);

ii) the Municipal Coastal Plan (MCP);

iii) the SIGERCO;

iv) the System for the Environmental Monitoring of the coastal zone (Portuguese acronym: SMA-ZC);

v) the Report of the Environmental Quality of the coastal zone (Portuguese acronym: RQA-ZC);

vi) the ZEEC and

vii) the Plan for Management of the coastal zone (Portuguese acronym: PGZC), which differs from the NCMP, because establishes more participation of society in its formulation and implementation .
It is observed that, although the actions are more or less specified, whether under a specific (Resolution № 005 , 1990) or a general (Resolution № 005, 1997) viewpoint, neither mentioned Resolutions defines a timeline for implementation, thus, making this process extremely slow. The presence of an implementation schedule, even with only some of the planned actions (given that there is still much to be done), would clearly place coastal management as a priority within the Brazilian government commitments.

\subsection{Analysis of some tools frequently used in Brazil- ian ICZM}

The three analyzed tools in this work utilizes the spatial planning as the main guideline. Taussik (2007: 612) analyzes the spatial planning tools and legislation in England and its intersection points with the ICZM goals: Spatial planning has a wider interpretation [than town and country planning]. It can be used to apply to any activity with a spatial, or geographical, dimension, be it on land or in marine environment, and concerns where a particular activity or development can be undertaken. Its tools including zoning, which can be combined with temporal controls. Coastal/marine activities demonstrating spatial dimensions include: new development, nature conservation, coastal defence and shoreline management; the regulation of minerals on and off-shore; and fisheries.

An analysis based on the guidelines of Federal Decree $\mathrm{N}^{\mathrm{o}}$ 4297, dated $10^{\text {th }}$ July 2002, which establishes criteria for the implementation of the EEZ, shows, from the natural environmental perspective, some consistency with the Handbook, especially for the parameters of biodiversity assessment and conservation, protection of ecologically important areas (such as breeding sites of species), primary productivity, recovery and preservation of areas for use and management of water resources. Also, the EEZ Decree comprises the premises of sustainable development, which is also concerned in Handbook: The process of elaboration and implementation of the EEZ: I - focus the ecological, economic and social sustainability, in order to reconcile economic growth and protection of natural resources, for both present and future generations (...)

However, except the determination of four classes of reference scale for generation of the EEZ cartographic charts, especially $1: 250.000$ to $1: 100.000$ for the coastal zone, no other specific methodological guidelines for coastal and maritime areas are cleared included. There is also no specified issues about what is considered vulnerability and potential assessment methodology, which innately leaves government agencies responsible for implementing it, although more detailed methodology is proposed in Macrodiagnostic. However, we observe 
methodological proposals for the establishment of EEZs from the Strategic Affairs Secretariat of the Presidency of the Republic (Portuguese acronym: SAE/PR) and Sustainable Development Secretariat of the Ministry of Environment (Portuguese acronym: SDS/MMA), although they contain only principles and general guidelines. On the other hand, it is noteworthy the organizational character of the instrument, which assumes the cooperation between the different spheres of public administration and the need to apply local criteria in evaluating the system.

Consideration of the geological/geomorphological aspects as well as description of oceanographic processes do not appear to be consistent within the guidelines of the EEZ (as defined in the Federal Decree № 4297/02) or within the ecological indicators of the Handbook. Although, some parameters presented in the Handbook appear in the CEEZ of Espírito Santo (Portuguese acronym: ZEEC-ES): wave climate, width of the continental shelf and geomorphology: In the context of geology and physics, the criteria were selected according to the availability of data and the possibility of satisfactory interpretations to ensure the representation of interactions, as suggested by Jimenez et al. (2008) and Muehe (2001), between: topography and geology; type / morphology of the coastline; and bathymetry and wave $d y$ namics. (IEMA, 2010: 135, authors translation).

Also appears in the CEEZ of Pernambuco (PE), (Portuguese acronym: ZEEC-PE) for example, as quality of water on the continental shelf. In the EEZ of Maranhão (MA) (Portuguese acronym: ZEE-MA), geomorphological aspects of the coast are observed, though not directly related to the coastal hydrodynamics processes.

Regarding socioeconomic variables, in general, there is notable consistence with the parameters affecting quality of life, represented in the guidelines of EEZ by health, labor market, housing, education and sanitation. Sustainable development, defined in the Handbook as the preservation of resources to be passed on to future generations, is contemplated and emphasized in the EEZ guidelines by acknowledging "the intrinsic value of biodiversity and its components".

The Orla Project, in this context, fills a systematization and coordination gap at the local level (specifically the City) regarding the coastal zone planning and management. Thus, the spatial focus of this project is the waterfront as an integral part of the coastal zone, responsible for its natural and economic support (MMA, 2005). From this premise, the Orla Project, divided into four deployment guides, aims at analyzing the shoreline regarding its natural (beach geomorphology, coastal dynamics, biodiversity and natural resources) and socioeconomic (real estate, industrial activity, tourism, fishing, others) features in order to classify, plan its development and regulate its use.
Observation of the physical-environmental factors (supporting information) included in the Orla Project aligns with the guidelines for diagnosis and planning suggested by the Handbook, which values the natural factors as important for planning purposes. The Orla Project stands out as another approach consistent with the Handbook, which addresses the legal question of the property regime of the coastal areas. Given the overlap between federal government, municipalities, and private lands, the basis for planning is prioritizing the resolution of legal disputes of land ownership, as well as the legal aspects applicable to every sphere of ownership. Hence, the legal consideration of the public beach, since construction of buildings very close to it can affect public access and use. Moreover, there are many property aspects and interests involved in shoreline occupation, making real estate adequacy a priority for planning purposes.

Meanwhile, the coastal zone shared management under the Orla Project, shows the importance given to public participation in the implementation of this project, raising awareness of its importance, execution of activities and decision-making. This displays another adequacy aspect, as is proposed in the basic guidelines of the Handbook which support decentralized management and popular participation in a bottom-up approach of the ICZM. The advantages of this decentralized strategy for the ICZM is in relief in Zagonari (2008), Ernoul (2010), Ballinger et al. (2010) and Cooper (2011).

Regarding the coverage of socioeconomic parameters suggested in the Handbook, the Macrodiagnostic disregards a wide range of issues that are critical to support activities of conservation and monitoring of the natural and cultural patrimony of the coastal zone (supporting information). For example, the Macrodiagnostic does not include total fluctuating population or some specific conditions for quality of housing (such as access to clean water or the houses located in hazardous areas) in Social Risk. In Technological Risk, it only includes activities related to the extraction and production of oil and natural gas (while there are a number of other economic activities that directly impact the coastal zone). It does not account for several different loads of pollutants and the introduction of ballast water, nor does it consider the amount of economic investment by government and private sector. It is noteworthy that much of this information is regularly produced by governmental bodies of nationwide jurisdiction like the Brazilian Institute of Geography and Statistics (Portuguese acronym: IBGE) and the Institute for Applied Economic Research (Portuguese acronym: IPEA).

Regarding coverage of ecological parameters suggested in the Handbook, it is observed that the Macrodiagnostic considers certain information related to biodiversity, but disregards other, oceanographic information, which 
is fundamental in Natural Risk, since it is related to primary (biomass and quality of habitat) and secondary productivity/production and to the risk of species extinction. In Technology Risk, it could include information related to fishing activities (e.g. quantifying by catch, adequacy of the fishing fleet, the level of government subsidy to fisheries development and the adequacy and control of fish farming activities). Unfortunately, much of this information suggested here is not systematically produced by government agencies, but can be so by state environmental agencies, provided there is a methodological standardization and coordination effort in this direction by Ministry of Environment. More broadly, the absence of such information reflects the still little attention paid by the Brazilian government to oceanographic monitoring, essential for the activities of the ICZM in the country, given its large coastline.

\subsection{Key Results}

Finally, the key results are summarized in the following lists. They are useful for the remark of the highlights obtained from this work. And an additional list with the cited legislation in the paper is also presented.

\subsubsection{Key results with respect to the analysis of the Brazilian NCMP}

- The analysis of the selected legislation related to the Brazilian NCMP (ICRS Resolution № 001/90 and ICRS Resolution № 005/97) showed some general characteristics of the Brazilian NCMP:

- The Brazilian NCMP includes the three level of governmental acting and provides mechanisms to its cooperation; also establishes the decentralization of strategy of the implementation and decision-making processes related to the ICZM in Brazil;

- The Brazilian NCMP establishes detailed zoning of the Brazilian coastal zone, considering two bands (one terrestrial and other, maritime). This zoning is used as guideline to the implementation of the tools related to the ICZM in Brazil;

- The inclusion of the municipalities that are not situated right on the waterfront in the Brazilian Coastal Zone shows the importance of the watershed as a geographical unit of analysis;

- There is a expressed commitment of the Brazilian government to the sustainable development of its coastal zone (in Resolution № 005/97), but the social and the ecological dimensions need to be better represented in the rules and tools provided to the implementation of the ICZM in Brazil; and

- The intervention level of the government in the Brazilian Coastal Zone still needs to be improved, because this is done mainly in the national level and could be extended to the others two spheres (state and municipal). The Brazilian government could act as a regulator of coastal areas in all the three governmental levels, so as not to allow the prevalence of speculative and vested interests in coastal management related decision-making;

\subsubsection{Key results with respect to the analysis of the se- lected tools}

- The EEZ is consistent with the biodiversity and conservation parameters as well as adopts an integrated view between different spheres of decisionmaking; However, it needs more detailed methodological guide, regarding a better adequacy between plans of different states;

- The Orla Project aims to understand the waterfront in a integrated view between natural and social aspects, as well as considers the property regime of the coastal areas. Still, fills a systematization and coordination gap at the local level (specifically the City) regarding the coastal zone planning and management;

- The Macrodiagnostic considers issues of biodiversity as well as introduces a more consistent methodology for coastal vulnerability assessment, but lacks of some oceanographic aspects; still, does not consider some social parameters as quality of housing or other important social issues, as suggested by the Handbook;

\section{Conclusions}

This work aimed to analysis the Brazilian NCMP and some of the most frequently used tools for performing the ICZM in Brazil. It was based on legislative, ecological and socioeconomic indicators suggested by the Handbook for measuring the progress and outcomes of the integrated coastal and ocean management, considered here as a valid representation of standardization and consistent coverage of indicators for sustainable coastal zone management, on international intergovernmental level, and especially because it is believed to be the only one in the world up to now in these terms. In this respect, Ye et al. (2014) cited the Handbook as a valid reference for the evaluation of the ICZM processes, based on the formulation of state and process indicators. The same authors accentuate the general absence of an integrated approach, between the socioeconomical, governmental and environmental coastal dynamics.

The analysis was also based in considerations presented in Gesamp (1996), about the global goal of the ICZM.

Results showed that the Brazilian NCMP seems to be adequate in defining and delimiting the coastal zone areas, in creating processes for institutional coordination and cooperation within the ICZM, and in planning for the use of the coastal zone. However, the Brazilian NCMP still need to include important aspects to meet 
the overall goal of the ICZM, which is improving the quality of life of the population living in coastal areas, conserving biological diversity and productivity of coastal ecosystems (GESAMP, 1996). A list of the key strengths and weaknesses of the Brazilian NCMP is showed below.

\section{Key strengths of the Brazilian NCMP}

- Establishes the competencies and the source of resources to operationalize the ICZM in Brazil and establishes mechanisms for cooperation (Resolution № 005, 1997);

- Establishes general standards for environmental management of the Brazilian Coastal Zone, determines the boundaries in which the guidelines of coastal management are to be followed, and delineates two bands covered by the plan: the maritime band and the terrestrial band;

- Includes, in the terrestrial band, municipalities that are not situated right on the waterfront (Resolution № 005, 1997). This providence is important, because includes municipalities that belong to the same watershed of the municipalities situated right on the waterfront, reinforcing the importance of the watersheds as an geographical unit of analysis;

- Is based on the decentralization of strategy implementation and decision-making, which specifically places the municipalities in the sphere of local implementation; this is important since municipalities acquire the knowledge of the coastal aspects and its environmental problems;

- Includes the three levels of government action;

- The commitment of the Brazilian government to the sustainable development of its coastal zone is clearly expressed in twelve principles (Resolution № 005 , 1997);

- Adopts components of the ICZM approach: geographic, temporal, sectoral and politicalinstitutional, according to Gesamp (1996); and

- Provides some tools to operationalize the ICZM in Brazil, including plans, systems for monitoring and reports;

\section{Key weaknesses of the Brazilian NCMP}

- Even if the ICRS Resolution № 005/97 contains the expressed commitment of the Brazilian government to the sustainable development of its coastal zone, the effects of socioeconomic activities are considered in this Resolution only on modelling the terrestrial domain and it does not clearly includes the marine domain. This is a serious shortcoming, since offshore oil exploration is becoming increasingly important in Brazil;
- Both two ICRS Resolutions (№ 001/90 and № 005/97), do not provide explicitly tools or actions to improve the quality life of the coastal populations who depends on coastal resources, which is one of the global goals of the ICZM, according to Gesamp (1996);

- Both two ICRS Resolutions (№ 001/90 and № 005/97) do not define clearly the preservation of the biological diversity and of the ecosystem productivity in the coastal zone, because it focuses on the sustainable use of natural resources (in the ICRS Resolution $\mathrm{N}^{\mathrm{o}} 001 / 90$ ), or physical changes in the coastal territory (in the ICRS Resolution $\mathrm{N}^{\text {o }}$ 005/97);

- Both the ICRS Resolutions (№ $001 / 90$ and № 005/97) do not clearly regulates the mandatory character of including the coastal management plans execution in the budgets of the three government levels;

- The government plays a lesser role on intervention activities in both ICRS Resolutions (№ 001/90 and $\mathrm{N}^{\mathrm{o}}$ 005/97), since only interventions at the local level are clearly defined. Thus, the Brazilian government is limited to providing information or planning; and

- Both the ICRS Resolutions (№ $001 / 90$ and № 005/97) do not define a timeline for implementation, thus, making the ICZM process extremely slow in Brazil. The presence of an implementation schedule, even with only some of the planned actions (given that there is still much to be done), would place practically the coastal management as a priority within the Brazilian government commitments.

Both EEZ and Orla Project are spatial planning tools with legal and conceptual support, albeit under different legal approaches. The EEZ is established legally by Federal Decree № 4297/02 (although already proclaimed by Article 225 of the Brazilian Federal Constitution of 1988 and the Federal Law $\mathrm{N}^{\mathrm{0}}$ 6938/81, the Brazilian National Environmental Policy). The Orla Project is based on several other existing legal aspects (Statute of Cities, NCMP, Property Regime Act, Federal Action Plan, among others), which already makes it consistent with the basis for the execution of the ICZM in Brazil, thus giving the necessary legal support.

The Orla Project appears to be more adequate regarding operational aspects when compared to the international references adopted in this work, despite the fact that the EEZ presents guidelines for the representation on a regional scale. However, both EEZ and Orla Project represent spatial planning tools applied to the ICZM in Brazil, albeit in different ways, which together strengthen the premise of planning as a biased categorization of sustainable development in the coastal zone. 
A list of the key strengths and weaknesses of the Brazilian NCMP is showed below.

\section{Key strengths of the selected tools}

- Are legally established by the Government;

- Are decentralized regarding to decision-making between the govern and other stakeholders;

- Are already implemented in some states, and are being reviewed in others, which leads to an improvement of Brazilian acquired experience;

- Focus on strategic planning and improvement of land use in the coastal zone;

- Embrace sustainable development as a premise as well as other relevant environmental issues concerned to the coastal zone;

- Are able to reflect local particularities for managing the coast.

\section{Key weaknesses of the selected tools}

- Although legally established by federal government, the tools have different legal character, but not mandatory;

- Lack of priority investments in the public spheres responsible for the tools management;

- Lack of uniform or more detailed methodology as a guide for some parameters of coastal vulnerability to climate changes, in order to homogenize the results of all Brazilian coastal states, especially which refers to CEEZ;

- Poor environmental data, especially the long term monitoring procedures, which are the basis for implementation of the coastal management tools.

It is noteworthy that the NCMP and all the tools analyzed in this may also include important aspects for the ICZM in Brazil, regarding the control of commercial and industrial activities (including accounting and controlling pollutant loads and introduction of ballast water), control of recreation activities, biodiversity quantification and protection (including biomass quantification and quality assessment of habitats) and the adequacy of fisheries and aquaculture (including quantifying and controlling by catch, adequacy of the fishing fleet, assessing fish farming ventures and quantifying the government subsidy level to fisheries development). The proposal to compare plans and coastal management tools in Brazil with the Handbook guidelines (IOC, 2006) does not intend to adopt or recommend a standard or completely based on international standards methodology. Evidently, the coastal zone has intrinsic local characteristics, in this sense, should the plans and management initiatives be flexible to suit local conditions. However, the purpose of this study was mainly detect the lack of parameters or management processes considered important in international level that may be useful for the development of coastal management in Brazil.

Finally, the results here obtained should be useful to contribute with the ICZM processes, in order to evaluate and detect the main strengths and weaknesses regarding the main plans and coastal planning initiatives in Brazil, and likewise, the main point congruence within the international reference management guide. Once the plans and initiatives should be reviewed periodically, this work can contribute suggestively in the adoption of detailed methodologies for local risk assessments to sea level variations and other forms of land use regulation. Additionally, this work aims to highlight the importance of the international parameters to the perfectioning the ICZM processes worldwide.

\section{Appendix}

Supporting Information associated with this article is available online at http://www.aprh.pt/rgci/pdf/rgci-531_Klumb-Oliveira_Supporting-Information.pdf

\section{Acknowledgements}

We would like to dedicate special thanks to the following persons: Dr. João Alveirinho Dias (Professor at the University of Algarve, Portugal), the Editor-in-Chief of the Journal of Integrated Coastal Management, and others anonymous reviewers of the paper, by their suggestions and corrections.

We also thank the Federal University of Rio de Janeiro and the National Council for Scientific and Technological Development of Brazil, to support this research.

\section{References}

Ballinger, R.; Pickaver, A.; Lymbery, G.; Ferreira, M. (2010) - An evaluation of the implementation of the European ICZM principles. Ocean \& Coastal Management, 53(12):738-749. DOI: 10.1016/j.ocecoaman.2010.10.013

Bird, E.C.F (1996) - Beach Management. 1. ed., 281p.. John Wiley \& Sons Ltd, Chinchester, NC, U.S.A. ISBN 0471963372.

Bossel, H. (1999) - Indicators for sustainable development: Theory, method, applications. 138p., International Institute for Sustainable Development, Canada. ISBN: 1895536138.

Cooper, J.A.G. (2011) - Progress in Integrated Coastal Zone Management (ICZM) in Northern Ireland. Marine Policy, 35(6):794799. DOI: $10.1016 /$ j.marpol.2011.01.002

Diegues, A.C.S. (2001) - Ecologia humana e planejamento em áreas costeiras. 2.ed., 191p., Núcleo de apoio à pesquisa sobre população humana e áreas úmidas brasileiras, São Paulo, SP, Brasil. ISBN: 8587304038.

Ernoul, L. (2010) - Combining process and output indicators to evaluate participation and sustainability in integrated coastal zone management projects. Ocean \& Coastal Management, 53(11):711-716. DOI: 10.1016/j.ocecoaman.2010.10.001

Ferreira, L.C. (1998) - A questão ambiental: sustentabilidade e políticas públicas no Brasil. 154p., Bomtempo, São Paulo, SP, Brasil. ISBN: 978-8585934279.

Freitas, M.A.P. (2007) - Zona costeira e meio ambiente: aspectos jurídicos. 231p., Juruá, Curitiba, PR, Brasil. ISBN: 8536209720.

GESAMP (1996) - The contributions of science to integrated coastal management. Gesamp Reports and Studies, n.61, 65p., 
GESAMP (Joint Group of Experts on the Scientific Aspects of Marine Environmental Protection), International Maritime Organization, Rome, Italy. ISBN: 978-9251038567. Available online at http://www.fao.org/3/a-w1639e/

GI-GERCO (1998) - Plano de Ação Federal para a Zona Costeira do Brasil. 34p., GI-GERCO (Grupo de Integração do Gerenciamento Costeiro), Ministério do Meio Ambiente, Brasília, DF, Brasil.

IEMA (2010) - Programa Estadual de Zoneamento EcológicoEconômico no Estado do Espírito Santo - PEZEE-ES. Relatório III: Diagnóstico geo-biofisico e Carta temática de Vulnerabilidade Natural. 265p., IEMA (Instituto Estadual de Meio Ambiente do Espírito Santo), Vitória, ES, Brasil. Available online at http://www.meioambiente.es.gov.br/download/Relatorio_III Diagnostico_Geobiologico.pdf

IOC (2006) - A Handbook for Measuring the Progress and Outcomes of Integrated Coastal and Ocean Management. Sherry Heileman, (ed.), 224p., IOC (Intergovernmental Oceanographic Comission), UNESCO, Paris, France. Available on-line at http://unesdoc.unesco.org/images/0014/001473/147313e.pdf

Komar, P. D. (1998) - Beaches Processes and Sedimentation. 2nd ed., 429p., Prentice Hall Inc., Upper Saddle River, N.J., U.S.A. ISBN: 0137549385.

Meadows, D. (1998) - Indicators and Information Systems for Sustainable Development. A Report to the Balaton Group. 78p., The Sustainability Institute, Hartland, VT, U.S.A. Available online at http://www.iisd.org/pdf/s_ind_2.pdf

MMA (1996) - Macrodiagnóstico da Zona Costeira do Brasil na Escala da União. 277p., Ministério do Meio Ambiente, dos Recursos Hídricos e da Amazônia Legal (MMA), Brasília, DF, Brasil.

MMA (2005) - Projeto Orla: guia de implementação. 36p., Ministério do Meio Ambiente, dos Recursos Hídricos e da Amazônia Legal, Secretaria de Qualidade Ambiental / Ministério do Planejamento, Orçamento e Gestão, Secretaria do Patrimônio da União, Brasília, DF, Brasil. Available on-line at http://www.mma.gov.br/estruturas/orla/_publicacao/11_publicacao2201 2009042111.pdf

MMA (2008) - Macrodiagnóstico da Zona Costeira e Marinha do Brasil. 242p., Ministério do Meio Ambiente, dos Recursos Hídricos e da Amazônia Legal (MMA), Brasília, DF, Brasil.

Moraes, A.C.R. (2007) - Contribuições para a Gestão da Zona Costeira do Brasil: Elementos para uma Geografia do Litoral Brasileiro. 232p., Hucittec, São Paulo, SP, Brasil. ISBN: 9788574196670.

Oliveira, M.R.L; Nicolodi, J.L (2012) - A Gestão Costeira no Brasil e os dez anos do Projeto Orla. Uma análise sob a ótica do poder público. Revista da Gestão Costeira Integrada 12(1):89-98 . DOI: $10.5894 /$ rgci308.

Pickaver, A.H.; Gilbert, C.; Breton, F. (2004) - An indicator set to measure the progress in the implementation of integrated coastal zone management in Europe. Ocean \& Coastal Management, 47: 449-462. DOI: 10.1016/j.ocecoaman.2004.06.001

Taussik, J. (2007) - The opportunities of spatial planning for integrated coastal management. Marine Policy, 31(5):611-618. DOI: 10.1016/j.marpol.2007.03.006
Ye, G.; Chou, L.M.; Yang, L.; Yang, S.; Du, J. (2014) - Evaluating the performance of Integrated Coastal Management in Quanzhou, Fujian, China. Ocean \& Coastal Management, 96:112122. DOI: 10.1016/j.ocecoaman.2014.05.010.

Zagonari, F. (2008) - Integrated coastal management: Top-down vs. community-based approaches. Journal of Environmental Management, 88(4):796-804. DOI: 10.1016/j.jenvman.2007.04.014.

\section{Legislation}

Lei $N^{o} 6.938$ de 31 de agosto de 1981. Dispõe sobre a Política Nacional do Meio Ambiente, seus fins e mecanismos de formulação e aplicação, e dá outras providências. DOU (Diário Oficial da União) (ISSN: 1676-2339), Ano CXIX, No. 167, Seção I, 02 de setembro de 1981, pp.16509-16512, Brasília, DF, Brasil. Available on-line at http://www.planalto.gov.br/ccivil 03/leis/16938.htm

Lei $N^{\circ} 7.661$ de 16 de maio de 1988. Institui o Plano Nacional de Gerenciamento Costeiro e dá outras providências. DOU (Diário Oficial da União) (ISSN: 1676-2339), Ano CXXVIII, Seção I, $\mathrm{N}^{\circ}$ 92, 18 de maio de 1988, pp.8633-8634, Brasília, DF, Brasil. Available on-line at http://www.planalto.gov.br/ccivil_03/leis/17661.htm

Decreto de 28 de dezembro de 2001. Dispõe sobre a Comissão Coordenadora do Zoneamento Ecológico-econômico do Território Nacional e o Grupo de Trabalho Permanente para a Execução do Zoneamento Ecológico-econômico, institui o Grupo de Trabalho permanente para a Execução do Zoneamento Ecológico-econômico, denominado de Consórcio ZEE-Brasil, e dá outras providências. DOU (Diário Oficial da União) (ISSN: 1676-2339), Seção I, No 247, 31 de dezembro de 2001, p.247, Brasília, DF, Brasil. Available on-line at http://www.planalto. gov.br/ccivil_03/dnn/2001/Dnn9465.htm

Decreto $N^{\circ} 4297$ de 10 de julho de 2002. Regulamenta o art. $9^{\circ}$, inciso II, da Lei $\mathrm{N}^{\circ} 6.938$, de 31 de agosto de 1981, estabelecendo critérios para o Zoneamento Ecológico- Econômico do Brasil - ZEE, e dá outras providências. DOU (Diário Oficial da União) (ISSN: 1676-2339), Seção I, No 132, 11 de julho de 2002, pp.6-7, Brasília, DF, Brasil. Available on-line at http://www.planalto.gov.br/ccivil_03/decreto/2002/d4297.htm

Decreto $N^{\circ} 5.300$ de 7 de dezembro de 2004. Regulamenta a Lei no 7.661, de 16 de maio de 1988, que institui o Plano Nacional de Gerenciamento Costeiro - PNGC, dispõe sobre regras de uso e ocupação da zona costeira e estabelece critérios de gestão da orla marítima, e dá outras providências. DOU (Diário Oficial da União) (ISSN: 1676-2339), Seção I, No 235, 08 de dezembro de 2004, pp.2-6, Brasília, DF, Brasil. Available on-line at http:// www.planalto.gov.br/ccivil_03/_ato2004-2006/2004/decreto/D5300.htm

Resolução da CIRM No 001 de 21 de novembro de 1990. Aprova o Plano Nacional de Gerenciamento Costeiro. Comissão Interministerial para os Recursos do Mar (CIRM), DOU (Diário Oficial da União) (ISSN: 1676-2339), Ano CXXVIII, Seção I, No 226, 27 de novembro de 1990, p.2263-2269, Brasília, DF, Brasil.

Resolução da CIRM No 005 de 03 de dezembro de 1997. Aprova o Plano Nacional de Gerenciamento Costeiro II (PNGC II). Comissão Interministerial para os Recursos do Mar (CIRM), DOU (Diário Oficial da União) (ISSN: 1676-2339), Ano CXXXVI, Seção I, No 9, 14 de janeiro de 1998, p.34-37, Brasília, DF, Brasil. 